\title{
A Religio-Cultural and Theological Discourse on the Trends and Issues of Female Circumcision in Nigeria
}

\author{
Sunday Sangotunde $\mathrm{PhD}$ \\ Department Of Religious Studies, Adeyemi College of Education, Ondo, Ondo State Nigeria
}

\begin{abstract}
The debate on female circumcision is a vital religious and cultural issue of great importance which has gathered international momentum in recent years. The practice, which is rampant in Nigeria topping the list of twenty-eight risk countries in Africa, deserves more attention and inquiries into its history, motives and justifications. This paper therefore examines the three major religious traditions in Nigeria-Christianity, Islam and African Traditional Religion; to establish its historical origin, motives, dimensions and justifications. The paper observes that the devastating psychological and physiological irreversible damages involved require a speedy and efficient intervention strategy so that the much desired change of attitudes of the individuals and groups in the practice could be quickly enhanced. The researcher adopts historical, exegetical and phenomenological approaches inhis enquiries. The researcher concludes by establishing that Christianity and Islam openly condemn and clearly prohibit all forms of mutilation or maiming of the body for any reason.The paper discovers that female circumcision is purely motivated by cultural heritage and assumes to have crept into religious mandates of Nigerians. The paper therefore recommends that once the origin is known the task of challenging the continuity in our modern society becomes easy and achievable.
\end{abstract}

Keywords: Circumcision, Culture, Genital, Physiological, Religion

\section{Introduction}

In many countries of the world, the female gender has always been subjected to all kinds of agonizing religious and traditional practices which are purposed to dehumanize women. One of such is the Female Genital Mutilation or Female Circumcision.The female circumcision could be described as the ritualistic removal of the external female genitalia typically carried out on a girl child or an adult woman in most African countries and a few Arabs, Asian, the Middle East and among the diaspora communities around the world ${ }^{1}$. Several reasons are mentioned for this much criticized practice ranging from fertility to the assumed control of the girl child sexual habit.

In any society in which it is practiced, female circumcision has become a manifestation of deeply entrenched gender inequality. This paper wants to see other reasons and probable origin aside of culture and religion because it is a practice supported by both men and women in most of the societies where it is practiced. Usually it is done without anyone asking questions, and a deviation from this norm may attract condemnation, harassment and ostracism from the family or community events. This paper aims at looking critically at whether religion permits female circumcision or whether it demands it. If religion permits it does it also demands for it for the fulfillment of any sacred rites associated with religious practices?

\section{Female Circumcision: A Cultural and Religious Debate}

Support for female circumcision relies mainly on arguments from tradition and religion. Traditionally it is believed that the girl child will not make a good wife if she is not circumcised. This practice has affected more than 130 million girls and women who have had partial or total removal of their external female genitalia or other injury to the female genital organs for cultural or religious reasons ${ }^{2}$.

The origin of the practice of female circumcision still remains complicated ${ }^{3}$. This is because the practice had been inexistence before the Christian and Islamic eras ${ }^{4}$. It has been discovered that historians such as Herodotus traced the origin of this practice to the $5^{\text {th }}$ century BC when it became a common and acceptable cultural practice of the Phoenicians, the Hittites and the Ethiopians 5 . 
When God decreed circumcision as a sign of the covenant with Abraham, it was intended to signify the covenant that existed between Himself and his chosen people as a whole. The practice in Genesis 17:9-11 means that when the male member of the family is circumcised, the entire family was counted and recognized as bearing the sign and the zeal of the divine covenant.

Hence, the word "you" in Genesis 17:11 which is a plural pronoun was used to refer to the entire group of people under this covenant arrangement and not only to an individual ${ }^{6,7}$. So circumcision of the male members in ancient Israel frequently represented the entire nation throughout the Old Testament. It was not a religious rite that could be reduced to signifying only that person's membership in the covenant arrangement from the Old Testament theological perspective. All the female members of the ancient Israel were part of the nation, and therefore, were recognized as bearing the covenant sign through his representation of the male counterparts who were mandated to undergo the rite of circumcision ${ }^{8}$. This is why female circumcision was not God's agenda for female's inclusion into His covenant rite (circumcision) with Abraham. Nowhere in the Old Testament could it be found that female genital organ should be mutilated.

In Jesus' time, baptism became a rite of acceptance into the divine grace and it continued to be seen as a sign required for someone to key into the covenant between God and His people. This shift clearly includes both males and females. Whereas, in the Old Testament; male circumcision rite is an indication of the superior rank of males within the covenant. Where then did female genital mutilation come from?

This paper traces the origin of female circumcision with the view of knowing the reasons behind its practice. This will enable the paper to establish or disprove the claim that female circumcision is to protect the girl child from harms and for ensuring marriage ability and fertility. Other issues such as pain, risk of infection and the alteration of the natural state are critical considerations involved in this practice.

Although, female circumcision is not sanctioned by either Christianity or Islam but those practicing it have supported themselves with one religious doctrine or the other'. Howevermany women where the practice is well known see female circumcision as a religious requirement and it is perceived as being connected to Islam and certain African Traditional Religions.

Looking at the Islamic response to female circumcision, it is observed that some individuals and groups have suspected Islam for the practice. However, the truth is that female circumcision is usually forced on children and adults by people from all religious faiths, including Islam, Christianity and African Traditional Religion in Nigeria. Even in Predominantly Christian countries like Eritrea and Ethiopia with $90 \%$ and $75 \%$ of the girls forced in to the practice, female circumcision has proved to be a cultural practice and devoid of any religious origin $^{10}$.

Furthermore, it is observed that those countries where the practice in common are often justified by some controversial sayings attributed to Prophet Mohammed that seems to favour sunna circumcision which involves minor cut on the clitoris. However, the authenticity of such statement cannot be ascertained ${ }^{11}$. The silence maintained by the Quran, the Old Testament the New Testament is interpreted to mean an acceptance of the practice by these various religious books. However, it is necessary to draw a line between permitting something to be practiced and demanding a thing as a religious practice.

Culturally, it is assumed that it reduces a woman's sexual desire and lessens temptations to have premarital and extra marital sex; thereby preserving a girl's virginity; which is a pre-requisite for marriage. Traditionally, it is assumed that female circumcision enhances hygiene and cleanliness because for a girl child to be considered as a complete woman and for female fertility, she has to be circumcised.The practice in Nigeria is supported by traditional beliefs, values and attitudes. In some communities it is valued as a rite of passage to womanhood. Others value it as a means of preserving a girl's virginity until marriage, for example among the Yoruba South western part of Nigeria. In most of the countries in Africa, female circumcision is a pre-requisite to marriage and marriage is vital to a woman's social and economic survival. It is believed by some African women that if their daughters are not circumcised she would not get husband. This harmful tradition has been guided by taboos from generation to generation in many African large and diverse communities. It is a cultural identity for community integration. In some communities in Nigeria, a girl child can not be considered an adult in a society unless she has undergone female circumcision. 
Religiously, female circumcision predates Judaism, Christianity and Islam. Though, religion is always cited as the reason, this paper observes that many of those who oppose to its practice deny that there is any proof of its link to religion. However, Islamic leaders in Nigeria are not unanimous on the subject.This paper noted that in multi-faith countries, it is often forced on girls whose families follow all faiths: Animism religions, Christianity, and Islam. For example, it is frequently practiced among Muslims, Christians and Animists in Ethiopia, Eritrea, Sierra Leone, and Sudan and Nigeria ${ }^{12}$.

The ritual has been so widespread that it could not have risen from a single origin ${ }^{13}$. The origin of female circumcision is fraught with controversy either as an initiation ceremony of young girls into womanhood or to ensure virginity and curb promiscuity, or to protect female modesty and chastity ${ }^{14}$. The practice transcends religious, geographical, and socio-economic boundaries. The initial form of circumcision mentioned in the Bible and Quran was about Abraham fulfilling the mandate of God. Theologically, this paper wishes to submit that it was in God's own divine will that female genital mutilation should not be done otherwise, they would have been included in the circumcision arrangement ordered by God in his covenant with Abraham. Probably Sarah would have been the first woman to have her clitoris removed either slightly or entirely just as Abraham first had his circumcision before any other member in his household.The paper observed that in many of its pages and chapters, the Bible makes no mention of prohibiting genital circumcision or mutilation to females, even though it does have rules regarding women and what women are and are not allowed to do. Also, there is no reference to it in the Quran. Though, it is also practiced in some Muslim countries in the world but the practice and its prevalent rate is not based on religious affinity but basically on ethnic identity. The silence maintained by Islam and Christianity over this matter makes the two religions susceptible by some researchers on the subject.

Platt observes that the dichotomy of opinions concerning thepractice creates conflict in the international community between those who adhere to thetradition of female circumcision and those who promote human rights by attempting to prohibitthe practice ${ }^{15}$. She opines further that those opposed to female circumcision must recognize that the practice is a type of religious and cultural belief ${ }^{16}$. Meanwhile, practitioners of female circumcision must become more informed about the procedure's potential health risks and possible alternatives to the extreme forms of the practice ${ }^{17}$.

\section{Conclusion and Recommendations}

This paper has observed that the history of female circumcision is not well known but the practice dated back at least 2000 years. It is not known when or where exactly this tradition originated from. It was believed that it was practiced in ancient Egypt as a sign of distinction amongst the aristocracy. Some believe it started during the slave trade when black slave women entered ancient Arab societies. Some believe that it began with the arrival of Islam in some parts of sub-Saharan Africa. Some believe the practice developed independently among certain ethnic groups in sub-Saharan Africa as part of puberty rites.

The paper discovered thatFemale circumcision is a harmful traditional practice that involves the cutting or removal of the female external genitals. It is typically found in traditional groups or community cultures all over the world but in varying degrees. The reasons for the practice, as noted in this research, are complex and the origins are often lost in the mists of time. This paper noted that in recent time, this practice has not enjoyed favourable comments for its practice and continuity. The reason is that female circumcision is seen as a manifestation of deeply entrenched gender inequality, a fact recognized by the $\mathrm{WHO}^{18}$.

This paper submits that the origins are obscure and there has been anthropological and historical research to help us understand how the practice came about. Although Female Circumcision is practiced in some communities in the belief that it is a religious requirement, research however shows that Female Circumcision pre-dates Islam and Christianity. Some researchers have traced the practice to Egypt in the fifth-century BC and argue that the geographical distribution of Female Circumcision suggests that it originated on the west coast of the Red Sea.Egyptian mummies show women infibulated and this is supported by a Greek papyrus in the British Museum dated 163 BC. A Greek historian and geographer in the second-century BC reported that a group along the eastern coast of the Red Sea cut their women in "Egyptian style" and that another group "cut off in infancy with razors the whole portion that others circumcise". Curiously, today female circumcision is referred to as "Pharaonic circumcisions" (i.e. Egyptian) in Sudan and "Sudanese circumcision" in Egypt". 
Therefore, this paper recommends that religious leaders should take active role in the awareness campaigns to eradicate the practice in Nigerian society. Although no religious scripts prescribe the practices but practitioners often believe that the practice has religious support. Religious leaders take varying positions with regard to female circumcision in a way promotes it, some consider it irrelevant and others contribute to its elimination. Religious Education designed to intimate religious groups about its dangers should be ignited by different religious and faith formulations in the country. Religious leaders should educate their followers about its devastating effects on the life and future of the girl child forced in to female circumcision in the society. Also, all and sundry, including religious practitioners should consider how the practice has been seen as a form of human right violation embedded in Nigeria constitution.

\section{References}

[1] Rogaia Mustafa Abusharaf. "Revising Feminist Discourses on Inbulation: The Hosken Reports in Shell-Duncan and Hemlund, 2000:165.

[2] United Nations High Commissioner for Human Rights. "Convention on the Rights of the Child", 1989. Available from http://www.unhchr.ch.

[3] United Nations Population Fund. "Female Genital Mutilation (FGM) Frequently Asked Questions", 2011. Available from http://www.unpf.femalegenitalmutilation.

[4] United Nations Population Fund. "Female Genital Mutilation", 2011.

[5] United Nations Population Fund. "Female Genital Mutilation", 2011.

[6] United Nations Population Fund. "Female Genital Mutilation", 2011.

[7] United Nations Population Fund. "Female Genital Mutilation", 2011.

[8] Ontario Consultants on Religious Tolerance. "Female Genital Mutilation: Debate About Africa", 2014.

[9] Ra McLaughlin. "Circumcision and Women". Knowledge Base. Available at www.thirdwill.org, 2013. Ra McLaughlin is the Vice President of Creative Delivery Systems at Third Millenium Online Ministries.

[10] Ra McLaughlin, "Circumcision and Women", 2013.

[11] Biblehub.com, "Genesis 17:10-11". Available at http://biblehub.com.org., 2014.

[12] Ra McLaughlin, "Circumcision and Women”, 2013.

[13] Sami A Aldeeb Abu-Sahlieh. "To Mutilate in the Name of Jehovah or Allah: Legitimization of Male and Female Circumcision",2010. Available from http://www.holyfeld.org.

[14] T.C. Okeke,USBAnyaehie, CCK Ezenyeaku. "An Overview of Female Genital Mutilation in Nigeria". Annals of Medical Health Sciences Research, 2:1, 2012:70- 73.

[15] T.C. Okeke,USBAnyaehie, CCK Ezenyeaku. "An Overview of Female Genital Mutilation in Nigeria”, 2012.

[16] Jessical Platt. "Female Circumcision: Religious Practice Versus Human Rights Violation", 2002:1.

[17] Jessical Platt. "Female Circumcision..”, 2002.

[18] Jessical Platt. "Female Circumcision..", 2002.

[19] WHO. "Female Genital Mutilation Factsheet No.241, 2013. Available from http://28toomany.letusendit.org. 